\title{
DOES INVESTMENT REPLACE AID AS COUNTRIES BECOME MORE DEVELOPED?
}

\author{
Helga Kristjánsdóttir ${ }^{1}$
}

\begin{abstract}
This paper looks at the correlation between aid inflow and foreign direct investment inflow to the heavily indebted poor countries Malawi, Mozambique and Ghana, classified as developing countries. Data covers World Bank measures for aid and foreign direct investment in these countries. Also, crop production index is accounted for, as well as current account balance, and the gross domestic product of the countries analyzed. Dataset runs from 1970 through 2004, using a simultaneous equation system to determine the interrelation. Due to the occasional small scale of flow, the inverse hyperbolic sine function is used, rather than a logarithmic function. Results indicate that when the sample countries experience a higher income per capita, complementary effects diminish at the cost of supplementary effects. Therefore, FDI can be considered to replace aid after a certain development has been reached within the developing economies analyzed. The answer to the paper title is yes, investment does replace aid as countries become more developed.
\end{abstract}

Key words: Foreign Direct Investment, Aid, Trade, Developing Countries.

JEL Classification: F21, F23

\section{Introduction}

The general belief has historically been that the recipients of foreign direct investment (FDI) from wealthy countries has been poorer countries. However, Markusen (2002) showed that the wealthy countries tend to invest in each other, so the flow of investment is primarily between the west and east, rather than from north to south, leaving the poorer African countries in an FDI wasteland. So what happens in the poorer countries? Many receive foreign aid, but is it doing its job? Does the aid improve the conditions in the countries to the extent that a country becomes able to attract FDI on its own? Can self-sufficiency be achieved for these chronic aid recipients? This paper aims to answer these questions, by looking at data from 1970 to 2004 for three African countries that are classified as heavily indebted poor countries (HIPC). All three have been receiving aid for the whole period studied, but all three have managed to attract some level of FDI in more recent years. What is the connection between the aid and the FDI? This is a challenging question, given the marginality of FDI inflow for the countries, because most functions to analyze FDI are really only designed for positive values. In this case, the zeros are also interesting and do have meaning, so a zero-friendly function is required. I therefore choose to use the Inverse Hyperbolic Sine functional format so the zeros in the data can be used

Corresponding author:

${ }^{1}$ University of Akureyri, Iceland

E-mail: helga@unak.is

ORCID: https://orcid.org/0000-0002-8857-8063

Researcher ID: S-1349-2018 productively, unlike a logarithmic function that simply ignores them. Furthermore, since the FDI and aid are so intertwined, I use the simultaneous equation system in order to explore the interrelation.

In the developing countries, FDI investment tends to be greenfield rather than brownfield, meaning that it's less likely to be in the form of joint ventures or mergers and acquisitions (M\&As). This means that FDI data is less convoluted in developing countries and the flow data can be applied directly rather than proxied by affiliate sales figures as done by Brainard (1997), Ekholm et al. (2003) or Markusen (2002). The paper is organized as follows. Section 2 sets out the literature and Section 3 explains the modelling strategy used and data. In Section 4 estimation results are presented. Finally, Section 5 provides summary and conclusions.

\section{Literature}

Available literature on FDI in the developing countries often tends to consider the contribution of FDI to growth, as shown in papers by De Mello (1997), Balasubramanyam et al. (1996) and Borensztein et al. (1998). Borensztein et al. (1998) suggest that the host country of FDI needs to have a minimum threshold of human capital, to experience higher productivity of FDI (Kristjánsdóttir, 2017; Kristjánsdóttir et al. 2017; Kristjánsdóttir, 2019). Some papers have looked at how 
FDI affects domestic firms in the local market, these would be papers like Aitken and Harrison (1999), and Aitken et al. (1997). Also, a paper by Edwards (1990) looks at debt-equity swaps in the developing countries.

Moreover, when considering aid flows and their contribution to shifting the economy into a higher equilibrium, a paper by Dalgaard et al. (2004) provides some interesting insights on how growth is impacted by aid flows, based on literature of some Burnside and Dollar papers. The variables selected in my paper somewhat correspond to the Dalgaard et al. (2004) paper.

Finding useful way to capture FDI has proven to be a difficult task, and therefore some researchers have chosen to look specifically into issues regarding that. In a paper by Lane and Milesi-Ferretti (2003) the concentration is set on the composition of FDI and possible ways of correcting for M\&As in the sample when estimating FDI.

In most of the recent literature, affiliate sales are commonly used as a proxy for FDI in a particular host country. With the objective of determining the shift between trade and multinational sales, Brainard (1997) analyzes multinational activities. In this wellknown paper, Brainard (1997) chooses to capture outward and inward FDI with separate measures as the share of affiliate sales in total exports, or to put it differently, share of overall foreign sales. More specifically, Brainard (1997) chooses to apply data on multinational activities in the United States, and countries trading with the United States. In her research, Brainard seeks to find ways to determine the willingness multinational enterprises have for entering into export, rather than overcoming the threshold of making foreign direct investment in a particular country. In her analysis, Brainard applies the proportion of export volume in overall corporate sales as the dependent variable, and this is measure is applied rather than applying sales of foreign affiliates in overall sales. The findings obtained by Brainard indicate that multinationals are more interested in entering into foreign production in the form of foreign direct investment than seeking to export to markets in other countries, following an increase in the cost of transporting and with an increase in barriers to invest. It also stimulates investment when conditions are such that foreign plant scale economies are increasing relative to scale economies of the firm.

Another more recent example of a share measure can be found in a paper by Slaughter (2000). Slaughter seeks to proxy foreign direct investment by using the share of majority owned affiliates in the total of investment made by multinationals.

On one hand Slaughter (2000) uses share of skilled labor in overall wage cost as the dependent variable of the equation, and the other hand he uses share of capital stocks an explanatory variable.

\section{Model and Data}

When choosing variables for the regressions, I use some of the variables Dalgaard et al. (2001) for estimating the connection between aid and growth. Since some of the sample data turn out to be negative, these are transformed by the inverse hyperbolic sine (IHS) procedure rather than the logarithm function.

A simultaneous equation model is applied here, which allows for simultaneous estimation of aid as function of foreign direct investment and investment as function of aid. More specifically, this procedure allows me to avoid the possible simultaneity which might exist among explanatory variables. I base the choice of variables somewhat on a paper by Dalgaard et al. (2004). In their paper Dalgaard et al.

(2004) use GDP, population, fraction of land in tropic, and budget surplus among other variables when estimating the interaction of aid and growth.

AID_inflowi,t $=\alpha 0+\alpha 1 F D I$ inflowi,t $+\alpha 2$ POPi,t (1) $+\overline{\alpha 3}$ GDPi,t $+01, i, t$

FDI_inflowi,t $=\alpha 4+\alpha 5 \mathrm{AID}_{\text {inflowi,t }}+\alpha 6 \mathrm{CROPi}, \mathrm{t}$ $+\alpha 7 \mathrm{CA}$ _balancei, $t+Q 2, \mathrm{i}, \mathrm{t}$

In Equation (1) the endogenous variables aid and FDI are functions of each other, as well as being function of other relevant variables for aid and FDI. The recipient country of FDI or aid, is denoted with (i), with the recipient countries being Ghana, Malawi and Mozambique.

Since I prefer to estimate the equation in a linear format, and change the notation, I now present it in a log-linear format as show in Equation (2). The model specification for the three-stage least-squares regression estimation for systems of simultaneous equations, for a linear regression format, can be presented as follows: $\sinh -1$ (AID inflowi,t $)=\beta 0+\beta 1 \sinh -1$ (FDI inflowi,t) (2) $+\beta 2 \sinh -\overline{1}(\mathrm{POPi}, \mathrm{t})+\beta 3 \sinh -1(\mathrm{GDPi}, \mathrm{t})+\zeta 1, \mathrm{i}, \mathrm{t}$ $\sinh -1$ (FDI_inflowi,t) $=\beta 4+\beta 5 \sinh -1$ (AID_inflowi,t) $+\beta 6 \sinh -1(\overline{C R O P i}, \mathrm{t})+\beta 7 \sinh -1(\mathrm{CA}$ _balancei, $\mathrm{t})+\zeta 2, \mathrm{i}, \mathrm{t}$

The simultaneous equation system presents AID inflow to the sample countries over time $(t)$ by (AID_inflowi,t) in Equation (2a), and FDI inflow over time $\overline{(t)}$ by (FDI_inflowi,t) in Equation (2b).

Foreign Direct Investment is obtained from the World Bank (2006B), and these are foreign direct investment data net inflows (BoP, current US\$).

During the period estimated, FDI flows, aid flows and the current account occasionally turn negative, within particular years. This can happen if dividend payment from the host country to the source country is higher than the investments made in a particular year.

As to deal with these cases of zeros and negatives, the dependent variables of FDI and aid are estimated by using the so-called inverse hyperbolic sine (IHS) procedure, rather than a logarithm transformation 1.

Generally, FDI is believed to give an indication of the long-term incentives of an investor, and can therefore potentially be considered to be a substitute for the International Development Association (IDA) 
Table 1

Variable Definition

\begin{tabular}{|c|c|}
\hline Variable & \\
\hline FDIi,t & The foreign direct investment data net inflows (BoP, current USD) into host country (i), over time ( $\mathrm{t}$ ). \\
\hline AIDi,t & $\begin{array}{l}\text { International Development Association (IDA) loans, which are defined as long-term no interest loans provided to the poorest } \\
\text { developing countries. IDA has the role of supporting anti-poverty programs in the host country }(i) \text {, over time }(t) \text {. }\end{array}$ \\
\hline Cropi,t & Crop production index $(1999-2001=100)$ in host country $(\mathrm{i})$, over time $(\mathrm{t})$ \\
\hline CAi,t & Current account balance (BoP, current USD) for country (i), over time ( $\mathrm{t}$ ). Pi,t Population, total in the host country (i), over time (t). \\
\hline GDPi,t & $\begin{array}{l}\text { Gross domestic product, current USD in the host country (i), over time }(\mathrm{t}) \text {. } \\
\text { The Aid, that is IDA financial flows into individual countries are defined by the World Bank (2006B) as net financial flows, AID (current } \\
\text { US\$). World Bank (2006B) defines net financial flows as the disbursements of loans and credits less repayments of principal. }\end{array}$ \\
\hline
\end{tabular}

Table 2

Summary Statistics

\begin{tabular}{|c|c|c|c|c|c|c|}
\hline Variable & Units & Obs & Mean & StD. & Min & Max \\
\hline FDI INFLOWi,t & current US\$ & 35 & $5.79 \mathrm{e}+07$ & $6.94 \mathrm{e}+07$ & $-1.83 \mathrm{e}+07$ & $2.44 \mathrm{e}+08$ \\
\hline AID INFLOWi,t & current US\$ & 35 & $1.11 \mathrm{e}+08$ & $9.35 \mathrm{e}+07$ & 2200000 & $2.45 \mathrm{e}+08$ \\
\hline CROPi,t & prod. index & 35 & 61.69143 & 26.97556 & 32.9 & 121.2 \\
\hline CA_BALANCEi,t & current US\$ & 30 & $-1.99 \mathrm{e}+08$ & $2.35 \mathrm{e}+08$ & $-9.64 \mathrm{e}+08$ & $2.55 \mathrm{e}+08$ \\
\hline POPi,t & total & 35 & $1.46 \mathrm{e}+07$ & 3975582 & 8982592 & $2.17 \mathrm{e}+07$ \\
\hline GDPi,t & current US\$ & 35 & $4.98 \mathrm{e}+09$ & $1.76 \mathrm{e}+09$ & $2.13 \mathrm{e}+09$ & $8.87 \mathrm{e}+09$ \\
\hline
\end{tabular}

loans, which are defined as long-term no interest loans provided to the poorest developing countries. IDA has the role of supporting anti-poverty programs.

The difference between the two functional forms is clearly visible for zeros and negative values.

In this paper the aggregate FDI World Bank (2006B) data is used together with IDA aid flow data from the World Bank (2006B). The other variables are defined by the World Bank (2006B) as follows: GDP (current US\$), Population (total), current account balance (BoP, current US\$), Crop production index $(1999-2001=100)$. I use data running from 1970 to 2004.

I use World Bank data for all the variables estimated, all estimates are received using STATA 8.0.

\section{Estimation Results}

The regression results from estimating level data Equation (1a) and Equation (1b) simultaneously for aid and FDI, are presented in Table 3.

The results from estimating Equation (1a) first present aid inflow(AID_inflowi,t) to the sample countries (Malawi, Mozambique and Ghana) as function of FDI inflow (FDI_inflowi,t), Population (POPi, $\mathrm{t}$ ) and gross domestic product, GDP (GDPi,t).

Then the results from estimating Equation (1b) are presented with FDI inflow as function of aid inflow, crop production and the current account balance.

The simultaneous equations for Ghana are somewhat as could be expected.

Taken together, in the case of Ghana, FDI and aid are not found to complement each other, that is they are found to be substitutes rather than complements. However, when Mozambique and Malawi are also included in the sample, FDI flows and aid flows are found to complement, rather than substitute, each other. Increase in aid inflows is found to significantly positively affect FDI inflow. These results can be found to support the hypothesis implying that when the HIPC countries experience a higher income per capita, as is the case for Ghana in comparison with Malawi and Mozambique $^{1}$, then complementary effects diminish, while supplementary effect increase with FDI inflows increasingly substituting for aid inflows.

Furthermore, as the estimates reported in Table 3 show, aid inflows are estimated to be positively affected by an increase in population and GDP. FDI is estimated to be positively affected by crop production, however negatively affected by the current account balance, these results are as could be expected.

Let us next look at the regression results obtained from estimating Equation (2), when using an inverse hyperbolic sine functional format (sinh-1) for all the variables. These results are presented in Table 4 . Before interpreting the results for Table 4, the historical development of the sample countries Ghana, Malawi and Mozambique deserves more attention. Ghana is sometimes viewed by international institutions as having a development success story, whereas Mozambique had civil war during the period analyzed, and Malawi suffered from dictatorship.

In Table 4, the logarithm equations represent elasticity coefficients, indicating the percentage change in dependent variable following a one percentage increase

${ }^{1} 1990$ Ghana had GDP 211, Malawi 131 and Mozambique 163, and in 2000 Ghana had GDP 251, Malawi 151 and Mozambique 211, these are GDPs (constant 2000 US\$), World Bank (2006B). 
Vol. 5, No. 2, 2019

Table 3

Empirical Findings for the Basic Model Specification

\begin{tabular}{|c|c|c|}
\hline Regressors & Ghana & Ghana, Moz., Malawi \\
\hline & Equation 1a & Equation 1a \\
\hline AID_inflowi,t & & $.120(0.91)$ \\
\hline FDI_inflowi,t & $-.202(-0.64)$ & $6.049^{* *}(1.96)$ \\
\hline POPi,t & $9.954(1.49)$ & $.010^{* *}(2.25)$ \\
\hline GDPi,t & $.034^{* * *}(3.07)$ & 77 \\
\hline Obs. & 30 & 0.4897 \\
\hline R-Sq. & 0.7018 & 77.98 \\
\hline$\chi^{2}$ & 72.75 & Equation $1 \mathrm{~b}$ \\
\hline FDI_inflowi,t & Equation 1b & $.393^{* *}(2.15)$ \\
\hline AID_inflowi,t & & $1363558^{* * *}(3.43)$ \\
\hline CROPi,t & $-.176(-1.08)$ & $-.154^{* * *}(-5.30)$ \\
\hline CA_BALANCEi,t & $2041060^{* * *}(4.95)$ & 77 \\
\hline Obs. & $-.1088126^{* *}(-2.79)$ & 0.5968 \\
\hline R-Sq. & 30 & 126.48 \\
\hline$\chi 2$ & 0.6298 & 57.06 \\
\hline
\end{tabular}

Note: t-statistics are in parentheses below the coefficients. ${ }^{* * *}{ }^{* *}$ and $^{*}$ denote significance levels of $1 \%, 5 \%$ and $10 \%$, respectively.

Table 4

Inverse Hyperbolic Sine Function Estimation

\begin{tabular}{|c|c|c|}
\hline Regressors & Ghana & Ghana, Moz., Malawi \\
\hline & Equation 2a & Equation 2a \\
\hline sinh-1(AID_inflowi,t) & & $.289(1.07)$ \\
\hline sinh-1(FDI_inflowi,t) & $.067(1.02)$ & $-1.430(-0.34)$ \\
\hline sinh-1(POPi,t) & $2.988(2.47)$ & $.307(0.30)$ \\
\hline sinh-1(GDPi,t) & $.565(0.86)$ & -0.3232 \\
\hline Obs. & 30 & 5.96 \\
\hline R-Sq. & 0.6598 & Equation 2b \\
\hline$\chi 2$ & 67.43 & $5.622(1.43)$ \\
\hline & Equation 2b & $-2.273(-0.27)$ \\
\hline sinh-1(FDI_inflowi,t) & & $.302(0.32)$ \\
\hline sinh-1(AID_inflowi,t) & $6.663(2.53)$ & 77 \\
\hline sinh-1(CROPi,t) & $-7.485(-1.29)$ & -1.3301 \\
\hline Obs. & $-.382(-0.52)$ & 5.16 \\
\hline R-Sq. & 30 & 129 \\
\hline$\chi 2$ & 0.1528 & 12.71 \\
\hline
\end{tabular}

Note: t-statistics are in parentheses below the coefficients. ${ }^{* * *},{ }^{* *}$ and ${ }^{*}$ denote significance levels of $1 \%, 5 \%$ and $10 \%$, respectively.

in one of the explanatory variables. The main conclusion to be drawn from Table 4 is that on the margin, aid inflow appears to complement FDI. Also, population is found to have more significant positive effects on aid than GDP, and crop less effect.

As for the whole sample, variables are found to be less significant than before.

\section{Summary and conclusions}

This research has the objective of determining whether aid flows and FDI inflows in some of the HIPC countries can be found to be supplements or complements, when analyzed over a period of time. Generally, FDI is believed to give an indication of the long-term incentives of an investor, and can therefore be considered to be substitute for International Development Association (IDA) loans, which are defined as long-term no interest loans to the poorest developing countries.

An important issue of concern is whether there is a shift from financial aid flows to FDI flows, when the economies move to a higher equilibrium, as reflected in higher income per capita. Estimates are obtained for the HIPC countries Ghana, Malawi and Mozambique, with Ghana having higher GDP than the other two countries. These countries are estimated together in one sample, and Ghana is also estimated individually as to provide a comparison to the other two countries.

One of the concerns to be considered in this context is that HIPC data may be somewhat troublesome. 
Flows may be zero values, or turn negative. There fore I choose to apply an inverse hyperbolic sine function in order as to deal with these countries, since that functional form allows for estimation of negative flows and zeros.

In conclusion, in the case of Ghana, FDI and aid are found to substitute, rather than complement each other. However, when Mozambique and Malawi are included in the sample, FDI flows and aid flows are found to complement each other.

Overall, the results can be found to support the theory that when the HIPC countries experience a higher income per capita, as in the case for Ghana in comparison with Malawi and Mozambique, complementary effects diminish at the cost of supplementary effects. With FDI inflows increasingly substituting for aid flows.

\section{Appendix A}

I use the definition by World Bank (2006A) on the Heavily indebted poor countries (HIPC) countries. These countries are:

Benin Bolivia Burkina Faso Burundi Cameroon Central African Republic Chad Comoros Congo, Dem. Rep. Congo, Rep. Côte d'Ivoire Ethiopia Gambia, The Ghana Guinea Guinea-Bissau Guyana Honduras Lao PDR Liberia Madagascar Malawi Mali Mauritania Mozambique Myanmar Nicaragua Niger Rwanda São Tomé and Principe Senegal Sierra Leone Somalia Sudan Tanzania Togo Uganda Zambia.

\section{Appendix B}

The Inverse Hyperbolic Sine function has a similar functional shape as the logarithm function for positive values. The Inverse Hyperbolic Sine Function can be presented as $\sinh -1(x)=\ln \left(x+\left(1+x^{\wedge} 2\right)^{\wedge} 0.5\right)$.

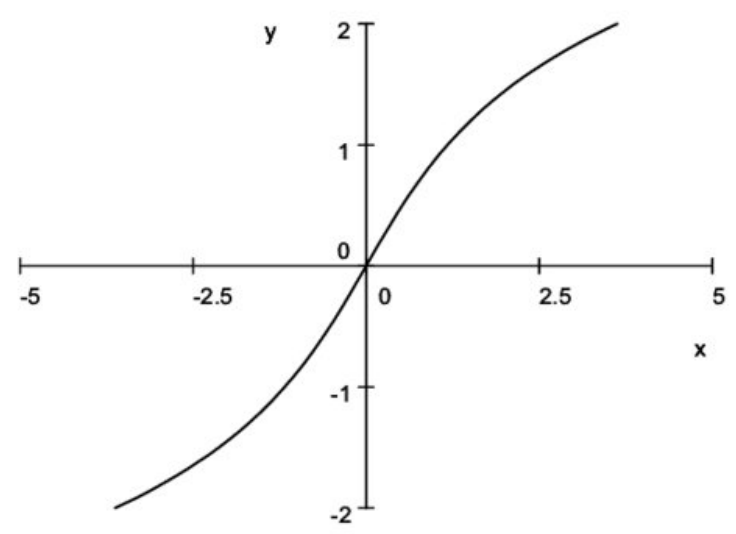

Figure 1. The Inverse Hyperbolic Sine function

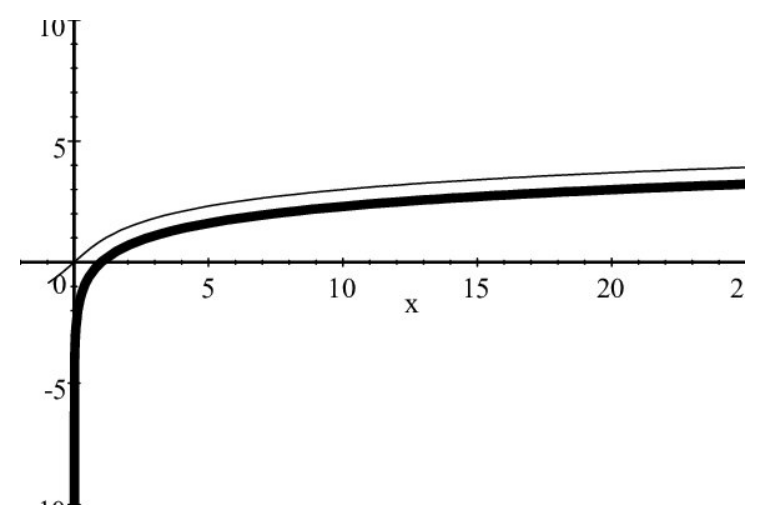

Figure 2. The Inverse Hyperbolic Sine function (thin line) and the natural logarithm function (thick line)

\section{References:}

Aitken B., G. H. Hanson and A. E. Harrison (1997). "Spillovers, Foreign Investment and Export Behaviour". Journal of International Economics 43.

Aitken B. and A. E. Harrison (1999). "Do Domestic Firms Benefit from Direct Foreign Investment? Evidence from Venezuela". The American Economic Review 89. 
Balasubramanyam V. N., Salisu M. and D. Sapsford (1996). "Foreign Direct Investment and Growth in EP and IS Countries". Economic Journal 106. No 434.

Borensztein E., De Gregorio J. and J. Lee. (1998). "How Does Foreign Direct Investment Affect Economic Growth?". Journal of International Economics 45.

Brainard, S. L. (1997). "An Empirical Assessment of the Proximity Concentration Trade-off Between Multinational Sales and Trade". American Economic Review, 87(4): 520-44.

Burbidge, J. B., Magee L. and A. L. Robb (1988). "Alternative Transformations to Handle Extreme Values of the Dependent Variable". Journal of the American Statistical Association 83 (March): 123-27.

Carroll, C., Dynan, K. and S. Krane (1999). "Unemployment Risk and Precautionary Wealth: Evidence from Households' Balance Sheets". Federal Reserve Board, Finance and Economics Discussion Paper No. 1999-15.

Dalgaard, C.-J. and Hansen, H. (2001). "On Aid, Growth and Good Policies". Journal of Development Studies, vol. 37, pp. 17-41.

Dalgaard, C.-J., H. Hansen and Tarp, F. (2004). "On the Empirics of Foreign Aid and Growth". The Economic Journal, Oxford.

De Mello Jr. L. R. (1997). "Foreign Direct Investment in Developing Countries and Growth: A Selective Survey". Journal of Development Studies 34.

Edwards S. (1990). "Capital Flows, Foreign Direct Investment, and Debt Equity Swaps in Developing Countries". NBER Working Paper 3497.

Ekholm K., Forslid R. and J. R. Markusen (2003). "Export-Platform Foreign Direct Investment". Discussion paper 2003-23. Centre for Economic and Business Research, Copenhagen.

Hanson, Gordon H., Mataloni, Raymond and Matthew J. Slaughter. "Expansion Strategies of U.S. Multinational Firms", in Dani Rodrik and Susan Collins (eds) Brookings Trade Forum 2001, 2001, pp. 245-294.

Helpman, Elhanan, Mark Melitz, and Stephen Yeaple (2004). "Export Versus FDI with Heterogeneous Firms". American Economic Review 94 (1), 300-316.

Headey, D. D., Rao D. S.P. and A Duhs (2004). "All the Conditions of Effective Foreign Aid". Working Paper Series No. 08/2004. Centre for Efficiency and Productivity Analysis. School of Economics University of Queensland.

Johnston, N. L. (1949). "Systems of Frequency Curves Generated by Methods of Translation". Biometrika 36: 149-76. Kristjánsdóttir, H. (2005). "What Drives Sector Allocation of Foreign Direct Investment in Iceland". EPRU Working Paper Series No. 2005-09, ISSN 09087745. University of Copenhagen.

Kristjánsdóttir, H. (2019). Cultural and geographical distance: Effects on UK exports. Applied Economics Letters. doi: 10.1080/13504851.2019.1613495

Kristjánsdóttir, H. (2017). Country Competitiveness: An Empirical Study. Baltic Region. 9(2): 31-44. doi: 10.5922/2079-8555-2017-2-3.

Kristjánsdóttir, H., Guðlaugsson, T., Guðmundsdóttir, S., and Aðalsteinsson, G.D. (2017). Hofstede National Culture and International Trade. Applied Economics. 49(57): 5792-5801. doi: 10.1080/00036846.2017.1343446. Lane P., Milesi-Ferretti Gian Maria (2003). "International Financial Integration". CEPR Working Paper DP3769.

Markusen, J.R. (1984). "Multinationals, Multi-plant Economies, and the Gains from Trade". Journal of International Economics, 16(3-4): 205-26.

Markusen, J. R. (1998). "Multinational Enterprises and the Theories of Trade and Location". In P. Braunerhjelm and K. Ekholm, eds., The Geography of Multinational Firms, Boston, Kluwer Academic Publishers, pp. 10-14.

Markusen, J. R. and Maskus K. E. (2001). "Multinational Firms: Reconcililing Theory and Evidence". In M. Blomstrom and L. S. Goldberg, eds., Topics in Empirical International Economics: A Festschrift in Honor of Robert E. Lipsey. Chicago, IL: University of Chicago Press for National Bureau of Economic Research.

Markusen, J. R., Venables, A. J., Eby-Konan, D., and Zhang, K. H. (1996). "A Unified Treatment of Horizontal Direct Investment, Vertical Direct Investment, and the Pattern of Trade in Goods and Services". NBER Working Paper 5696. National Bureau of Economic Research, Cambridge, MA.

Markusen, J. R. (2002). Multinational Firms and the Theory of International Trade, Cambridge, MA: MIT Press.

Markusen, J. R. and Maskus K. E. (2002). "Discriminating among Alternative Theories of the Multinational Enterprise". Review of International Economics, 10(4), 694-707.

Razin A., Rubinstein Y. and E. Sadka (2003). "Which Countries Export FDI, and How Much?". Paper presented at the 6th Conference of the Analysis of International Capital Markets RTN, hosted by: Universita di Roma III, December 2003. Downloaded from: www.cepr.org March 30th, 2004, pp. 2-4.

Slaughter, M. J. (2000). "Production Transfer Within Multinational Enterprises and American Wages". Journal of International Economics, 50(2), pp. 449-472.

World Bank (2006A). "World Bank list of economies". Downloaded from: http://web.worldbank.org April 6th. World Bank (2006B). "Development Indicators". Downloaded from: http://publications.worldbank.org/ subscriptions/WDI/ April 6th 